\title{
PENYELESAIAN ATAS KEADAAN FORCE MAJEURE PADA RUMAH SUSUN YANG MASIH DALAM PROSES PEMBANGUNAN
}

\author{
Oleh : \\ Made Intan Permatasari ${ }^{1}$
}

\begin{abstract}
The flat is one of the most popular alternatives of housing due to limited land availability. In the construction of flats, the developer will usually ask for a down payment to consumers who want to order the apartment of flat units. The problem occurs when a force majeure occurs at the time the apartment is still under construction. The problems of the study: What are the legal consequences in case of force majeure of under construction flat? And how is the settlement of force majeure situation under construction flat? The research method used is normative research. The results of the discussion show that (1) The legal consequence of the occurrence of force majeure at the time of the flats is still in the process of construction that the consumer can no longer request the fulfillment of the agreement; The debtor can no longer be declared negligent, and therefore it is not obliged to pay compensation; (2) The settlement effort in case of force majeure condition if the flats are still under construction process: Settlement through consensus agreement between the developer and the consumer to find joint settlement of the occurrence offorce majeure and settlement of loss through insurance, so that insurance claims may be used to rebuild the flats.
\end{abstract}

Keywords: legal consequences, developer, force majeure, flats

\begin{abstract}
Abstrak
Rumah susun merupakan salah satu alternatif perumahan yang banyak diminati saat ini karena lahan yang tersedia sangat minim. Dalam pembangunan rumah susun, pihak pengembang biasanya akan meminta uang muka kepada konsumen yang hendak memesan unit rumah susun tersebut. Permasalahan terjadi apabila pada saat rumah susun masih dalam proses pembangunan kemudian terjadi keadaan force majeure. Permasalahan yang terjadi yaitu Bagaimanakah akibat hukum apabila terjadi force majeure pada rumah susun yang masih dalam proses pembangunan? Dan Bagaimanakah penyelesaian atas keadaan force majeure pada rumah susun yang masih dalam proses pembangunan? Metode penelitian yang dipergunakan yaitu penelitian normatif. Hasil pembahasan dapat diketahui bahwa (1) Akibat hukum terjadinya keadaan force majeure pada saat rumah susun masih dalam proses pembangunan yaitu tidak lagi dapat meminta pemenuhan prestasi; Debitur tidak lagi dapat dinyatakan lalai, dan karenanya tidak wajib membayar ganti rugi; (2) Adapun upaya penyelesaian apabila terjadi keadaan force majeure apabila rumah susun yang masih dalam proses pembangunan yaitu: Penyelesaian melalui musyawarah mufakat antara pihak pengembang selaku developer dengan pihak konsumen untuk menemukan penyelesaian

1 Program Studi Magister Ilmu Hukum, Fakultas Hukum, Universitas Udayana, Denpasar-Bali, email: madeintanps@gmail.com
\end{abstract}


bersama atas terjadinya keadaan force majeure dan Penyelesaian kerugian yang dilakukan melalui asuransi, sehingga klaim asuransi nantinya dipergunakan untuk melakukan pembangunan kembali rumah susun tersebut.

\section{Kata kunci: akibat, pengembang, force majeure, rumah susun}

\section{PENDAHULUAN}

Dalam pembentukan kepribadian bangsa sebagai upaya membangun manusia Indonesia yang berjati diri, mandiri, dan produktif dibutuhkan pemenuhan dimana setiap orang berhak atas hidup sejahtera lahir dan batin, bertempat tinggal, dan mendapatkan lingkungan yang hidup yang baik dan sehat.

Berdasarkan ketentuan yang diatur dalam Pasal $28 \mathrm{H}$ ayat (1) UUD NKRI 1945 menyatakan bahwa : "setiap orang berhak hidup sejahtera lahir dan batin, bertempat tinggal dan mendapatkan lingkungan hidup yang baik sehat serta berhak memperoleh pelayanan kesehatan." Ketentuan pasal ini dapat diketahui bahwa terpenuhinya kebutuhan akan perumahan, yang merupakan kebutuhan dasar bagi setiap Warga Negara Indonesia, merupakan salah satu unsur pokok kesejahteraan rakyat.

Di Indonesia, terutama masyarakat perkotaan mengalami peningkatan terhadap kebutuhan perumahan. Bertambahnya populasi penduduk secara pesat dan adanya kendala keterbatasan lahan perumahan, memaksa pemerintah untuk berupaya memenuhi kebutuhan dalam hal ini perumahan. ${ }^{2}$ Pemukiman

2 Erwin Kallo, 2009, Panduan Hukum Untuk Pemilik/Penghuni Rumah Susun, Minerva Athena Pressindo, Jakarta, hlm. 25 dan perumahan adalah kebutuhan utama/primer yang harus dipenuhi oleh manusia. Dalam rangka menciptakan suatu tatanan hidup untuk masyarakat dalam menampakkan jati diri, perumahan dan pemukiman merupakan hal penting yang tidak hanya dapat dilihat sebagai sarana kebutuhan hidup, tetapi adalah sebagai proses bermukim manusia.

Untuk selanjutnya dengan adanya kendala keterbatasan lahan perumahan, maka perlu dilakukan penataan atas tanah, sehingga pemanfaatannya benar-benar dapat dirasakan oleh masyarakat banyak. Salah satu alternatif dalam pemecahan masalah kebutuhan pemukiman dan perumahan pada lokasi yang padat dan terbatas, yaitu pembangunan rumah susun yang lengkap, seimbang, dan serasi dengan lingkungannya. ${ }^{3}$ Melalui pembangunan rumah susun, optimalisasi penggunaan tanah secara vertikal sampai beberapa tingkat akan lebih efektif daripada optimalisasi penggunaan secara horizontal. ${ }^{4}$

Konsep dari rumah susun ini berupa bangunan bertingkat, yang dapat dihuni bersama atau satuan dari

3 Arie S. Hutagalung, 2007, Kondominium dan Permasalahannya, BPFH Universitas Indonesia, Jakarta, hlm. 2

4 Ridwan Salim, 2002, Sendi-Sendi Hukum Hak Milik, Kondominium, Rumah Susun dan SariSari Hukum Benda, Puncak Karna, Jakarta, hlm. 299 
unit dalam bangunan dimaksud dapat dimiliki secara terpisah yang dibangun baik secara horizontal maupun secara vertikal sesuai dengan kebutuhan masyarakat. $^{5}$

Ketentuan mengenai rumah susun sat ini diatur dalam UndangUndang Nomor 20 Tahun 2011 tentang Rumah Susun (selanjutnya disebut UU Rumah Susun) untuk mengganti Undang-Undang Nomor 16 Tahun 1985 tentang Rumah Susun. Menurut ketentuan yang diatur dalam Pasal 1 angka 1 UU Rumah Susun memberi pengertian rumah susun adalah bangunan gedung bertingkat yang dibangun dalam suatu lingkungan yang terbagi dalam bagian-bagian yang di strukturkan secara fungsional, baik dalam arah horizontal maupun vertikal dan merupakan satuan-satuan yang masing-masing dapat dimiliki dan digunakan secara terpisah, terutama untuk tempat hunian yang dilengkapi dengan bagian bersama, benda bersama dan tanah bersama. Pemilikan Satuan Rumah Susun (selanjutnya disebut Sarusun) adalah bersifat perorangan dan terpisah dengan hak bersama, benda bersama dan tanah bersama.

Permasalahan terkait dengan rumah susun menjadi masalah yang krusialapabilabangunangedungrumah susun tersebut roboh atau terbakar akibat terjadinya keadaan memaksa atau force majeure diluar kehendak baik pihak developer maupun pihak pembeli selaku konsumen pada saat

51Andrian Sutedi, 2010, Hukum Rumah Susun dan Apartemen, Sinar Grafika, Jakarta, hlm. 162163 rumah susun tersebut masih dalam proses pembangunan. Hal ini tentunya berdampak pada uang muka yang telah dibayarkan oleh pihak konsumen kepada developer sebagai tanda jadi keseriusannya untuk membeli unit rumah susun tersebut.

Keadaan memaksa adalah suatu keadaan tidak terduga, tidak disengaja, dan tidak dapat dipertanggung jawabkan oleh debitur, dimana debitur tidak dapat melakukan prestasinya kepada kreditur dan dengan terpaksa peraturan hukum juga tidak diindahkan sebagaimana mestinya, hal ini disebabkan adanya kejadian yang berada di luar kekuasaannya dan keadaan ini dapat dijadikan alasan untuk dibebaskan dari kewajiban membayar ganti kerugian. ${ }^{6}$

Berdasarkan latar belakang sebagaimana diuraikan diatas, maka menarik untuk dibahas lebih lanjut dalam penulisan jurnal ini dengan mengangkat judul "Penyelesaian Atas Keadaan Force Majeure Pada Rumah Susun Yang Masih Dalam Proses Pembangunan.'

Dengan latar belakang tersebut diatas, adapun permasalahan yang dapat dikaji, yaitu bagaimanakah akibat hukum apabila terjadi force majeure pada rumah susun yang masih dalam proses pembangunan? dan bagaimanakah penyelesaian atas keadaan force majeure pada rumah susun yang masih dalam proses pembangunan?

6 Handri Rahardjo, 2009, Hukum Perjanjian Di Indonesia, Pustaka Yustisia, Yogjakarta, hlm. 104 
Penelitian ini adalah karya ilmiah asli yang belum pernah diteliti sebelumnya. Adapun karya ilmiahyang terkait dengan karya ilmiah Penulis tentang Penyelesaian Atas Keadaan Force MajeurePadaRumah Susunyang Masih Dalam Proses Pembangunan yaitu karya ilmiah dari Indah Erfira dan I Made Walesha Putra tahun 2015 berjudul Tinjauan Yuridis Terhadap Kepemilikan Hak Atas Tanah Pada Satuan Rumah Susun, dengan rumusan masalahnya adalah bagaimana dasar hukum terhadap kepemilikan hak atas tanah pada satuan rumah susun? ${ }^{7}$ Karya ilmiah lainnya yang terkait yaitu Randy Sujateruna, I Gusti Ayu Puspawati dan Suatra Putrawan tahun 2015 yang berjudul Perlindungan Hukum Bagi Konsumen Pembeli Satuan Rumah Susun Terhadap Status Kepemilikan Satuan Rumah Susun, dengan rumusan masalah yaitu apabila tanah tempat dibangunnya rumah susun tersebut berstatus hak milik dan tanah tersebut dipindah alihkan kepada orang lain, bagaimana status kepemilikan para penghuni satuan rumah susun? ${ }^{8}$ Selanjutnya karya ilmiah Rakhma Yulia Hastuty tahun 2015 berjudul Perlindungan Hukum

7 Erfira, I., \& Walesa Putra, I. Tinjauan Yuridis Terhadap Kepemilikan Hak Atas Tanah Pada Satuan Rumah Susun. Kertha Negara, 3(02). https://ojs.unud.ac.id/index. php/Kerthanegara/article/view/13084, diakses pada tanggal 18 Januari 2018

8 Sujateruna, R., Puspawati, I., \& Putrawan, S. Perlindungan Hukum Bagi Konsumen Pembeli Satuan Rumah Susun Terhadap Status Kepemilikan Satuan Rumah Susun. Kertha Semaya, 2(06). https://ojs.unud.ac.id/index. $\mathrm{php} /$ Kerthanegara/article/view/10270, diakses pada tanggal 18 Januari 2018
Terhadap Konsumen Dalam Jual Beli Rumah Susun Komersial yang Belum Dibangun dengan rumusan masalah yaitu bagaimana bentuk perlindungan hukum terhadap konsumen dalam perjanjian jual beli rumah susun komersial yang belum dibangun dan upaya hukum apa yang dapat dilakukan oleh pihak konsumen, apabila pelaku/ pihak pembangun tidak melakukan prestasinya (membangun rumah susun komersial)? ${ }^{9}$ Tampak jelas adanya perbedaan dari karya ilmiah tersebut dengan karya ilmiah yang dibuat oleh Penulis. Perbedaan karya ilmiah ini dengan karya ilmiah lainnya yaitu karya ilmiah ini lebih membahas bagaimana akibat hukum apabila terjadi force majeure pada rumah susun yang masih dalam proses pembangunan dan penyelesaian atas keadaan force majeure pada rumah susun yang masih dalam proses pembangunan. Secara umum penelitian ini bertujuan untuk pengembangan ilmu hukum terkait paradigma Science as a process (ilmu sebagai proses). Dengan paradigma ini, ilmu hukum tidak akan mandek dalam penggalian atas kebenaran, khususnya terkait dengan materi Penyelesaian Atas Keadaan Force Majeure Pada Rumah Susun Yang Masih Dalam Proses Pembangunan. Sedangkan yang menjadi tujuan khusus adalah :

9 Hastuty, R. Y. (2015). Perlindungan Hukum Terhadap Konsumen Dalam Jual Beli Rumah Susun Komersial Yang Belum Dibangun. Jurnal Mahasiswa Fakultas Hukum.,http:// hukum.student-journal.ub.ac.a.id/index. php/hukum/article/view/1315, diakses pada tanggal 18 Januati 2018 
1. Untuk meneliti akibat hukum apabila terjadi force majeure pada rumah susun yang masih dalam proses pembangunan.

2. Untuk mendeskripsikan dan melakukan analisis secara mendalam mengenai: penyelesaian atas keadaan force majeure pada rumah susun yang masih dalam proses pembangunan.

\section{METODE PENELITIAN}

Jenis penelitian yang digunakan dalam penelitian tesis ini yaitu penelitian hukum normatif, berangkat dari terjadinya konflik karena terjadi kekosongan norma terkait dengan pemberian ganti rugi apabila terjadi keadaan force majeure pada satuan rumah susun yang masih dalam proses pembangunan. Penelitian hukum Normatif mencakup penelitian terhadap sistematika hukum, penelitian terhadap taraf sinkronisasi hukum, penelitian sejarah hukum dan penelitian perbandingan hukum. ${ }^{10}$

Dalam penulisan ini, masalah yang ada dalam penelitian ini dibahas menggunakan jenis pendekatan perundang-undangan

(statute approach) dasar awal melakukan analisis, jenis pendekatan konsep (conseptual approach) dalam ilmu hukum yang dapat dijadikan titik tolak atau pendekatan bagi analisis penelitian hukum, dan pendekatan analitis (Analytical Approach) pendekatan ini 10 Soerjono Soekanto, 2006, Pengantar Penelitian Hukum, UI Press, Jakarta, hlm. 51 dilakukan dengan mencari makna pada istilah-istilah hukum yang terdapat di dalam perundang-undangan, dengan begitu peneliti memperoleh pengertian atau makna baru dari istilah-istilah hukum dan menguji penerapannya secara praktis dengan menganalisis putusan-putusan hukum. ${ }^{11}$

Sumber bahan hukum yang dipergunakan yaitu bahan hukum primer yang bersumber dari bahan hukum primer yaitu berupa peraturan perundang-undangan, bahan hukum sekunder yang terdiri dari literaturliteratur, buku-buku, makalah, dokumen-dokumen yang berkaitan dengan masalah yang dibahas, Bahanbahan hukum sekunder yang berupa buku-buku hukum ini harus relevan dengan topik penelitian. ${ }^{12}$ dan bahan hukum tertier merupakan bahan yang dapat memberikan petunjuk maupun penjelasan terhadap bahan hukum primer dan sekunder, seperti kamus, ensiklopedi dan seterusnya. ${ }^{13}$

Teknik pengumpulan bahan hukum yang dipergunakan dalam penelitian ini adalah melalui studi kepustakaan, yaitu memahami dan mengkaji lebih mendalam tentang literatur dan peraturan perundangundangan yang ada kolerasinya dengan

11 Mukti Fajar, dan Yulianto Achmad, 2010, Dualisme Penelitian Hukum Normatif \& Empiris, Pustaka Pelajar, Yogjakarta, hlm. 185-190

12 Persada J. 2003, Penelitian Hukum Normatif Suatu Tinjauan Singkat, Rajawali Press, Jakarta, hlm. 13-14.

13 Bambang Waluyo, 2002, Penelitian Hukum Dalam Praktek, Sinar Grafika, Jakarta, hlm. 23 
pembahasan baik langsung maupun tidak langsung. ${ }^{14}$

Teknik analisis bahan hukum yang diterapkan dalam penelitian ini diawali dengan pengumpulan bahan-bahan hukum yang diperoleh untuk kemudian dianalisis. Analisis dilakukan dalam rangka untuk menyelesaikan permasalahan yang ada dengan menggambarkan apa yang menjadi masalah (deskripsi), menjelaskan masalah (eksplanasi), mengkaji permasalahan dari bahanbahan hukum yang terkait (evaluasi) dan memberikan argumentasi dari hasil evaluasi tersebut, sehingga didapat kesimpulan mengenai persoalan yang dibahas pada penelitian ini.

III. HASIL DAN PEMBAHASAN 3.1 Akibat Terjadinya Force Majeure Pada Rumah Susun Yang Masih Dalam Pembangunan oleh Pihak Pengembang

Pengembang perumahan (real estate developer) atau biasa juga disingkat pengembang/developer adalah perusahan atau perorangan yang bekerja mengembangkan suatu kawasan permukiman menjadi perumahan yang layak huni dan memiliki nilai ekonomis sehingga dapat dijual kepada masyarakat. ${ }^{15}$

14 Amiruddin dan H. Zainal Asikin, 2004, Pengantar Metode Penelitian Hukum, PT. RajaGrafindo Persada, Jakarta,hlm. 58.

15 R. Serfianto Dibyo Purnomo, Iswi Hariyani dan Cita Yustisia, 2011, Kitab Hukum Bisnis Properti, Pustaka Yustisia, Yogjakarta, hlm. 11
Pengembang perumahan sebagaimana diatur dalam ketentuan Undang-Undang Nomor 1 Tahun 2011 tentang Perumahan dan Kawasan Permukiman (selanjutnya disebut UU No. 1 Tahun 2011), pengembang perumahan masuk dalam kategori penyelenggara atau pengembang pembangunan perumahan dan pemukiman yang penyelenggaraan rumah dan perumahan dilaksanakan oleh Pemerintah, Pemerintah Daerah dan/atau setiap orang untuk menjamin hak setiap warga Negara untuk menempati, menikmati, dan/atau memiliki rumah yang layak dalam lingkungan yang sehat, aman, serasi, dan teratur.

Terdapat beberapa asas terkait dengan penyelenggaraan rumah susun. Menurut ketentuan Pasal 2 UU Rumah Susun asas-asas pembangunan rumah susun dapat diuraikan sebagai berikut yaitu, asas kesejahteraan dimana merupakan kondisi terpenuhinya kebutuhan rumah susun yang layak bagi masyarakat agar mampu mengembangkan diri sehingga dapat melaksanakan fungsi sosialnya, asas keadilan dan pemerataan yang dapat memberikan hasil pembangunan di bidangrumahsusunagardapatdinikmati secara proporsional dan merata bagi seluruh rakyat, asas kenasionalan yaitu landasan agar kepemilikan sarusun dimanfaatkan sebesar-besarnya untuk kepentingan nasional, selanjutnya asas keterjangkauandankemudahansebagai landasan agar hasil pembangunan 
rumah susun dapat dijangkau oleh seluruh lapisan masyarakat, serta mendorong terciptanya iklim kondusif, asas keefisienan dan kemanfaatan yang merupakan landasan penyelenggaraan rumah susun yang dilakukan dengan memaksimalkan potensi sumber daya tanah, teknologi rancang bangun, dan industri bahan bangunan yang sehat serta memberikan kemanfaatan sebesar besarnya bagi kesejahteraan rakyat, asas kemandirian dan kebersamaan sebagai landasan penyelenggaraan rumah susun bertumpu pada prakarsa, swadaya, dan peran serta masyarakat sehingga mampu membangun kepercayaan, kemampuan, dan kekuatan sendiri serta terciptanya kerja sama antar pemangku kepentingan, asas kemitraan dimana merupakan landasan agar penyelenggaraan rumah susun dilakukan oleh Pemerintah dan pemerintah daerah dengan melibatkan pelaku usaha dan masyarakat dengan prinsip saling mendukung, asas keserasian dan keseimbangan yang dapat memberikan landasan agar penyelenggaraan rumah susun dilakukan dengan mewujudkan keserasian dan keseimbangan pola pemanfaatan ruang, asas keterpaduan sebagai landasan agar rumah susun diselenggarakan secara terpadu dalam hal kebijakan dalam perencanaan, pelaksanaan, pemanfaatan, dan pengendalian, asas kesehatan yang dapat memberikan landasan agar pembangunan rumah susun memenuhi standar rumah sehat, syarat kesehatan lingkungan, dan perilaku hidup sehat, asas kelestarian dan keberlanjutan sebagai landasan agar rumah susun diselenggarakan dengan menjaga keseimbangan lingkungan hidup dan menyesuaikan dengan kebutuhan yang terus meningkat sejalan dengan laju pertumbuhan penduduk dan keterbatasan lahan, asas keselamatan, kenyamanan, dan kemudahan sebagai landasan agar bangunan rumah susun memenuhi persyaratan keselamatan, yaitu kemampuan bangunan rumah susun mendukung beban muatan, pengamanan bahaya kebakaran, dan bahaya petir; persyaratan kenyamanan ruang dan gerak antar ruang, pengkondisian udara, pandangan, getaran, dan kebisingan; serta persyaratan kemudahan hubungan ke, dari, dan di dalam bangunan, kelengkapan prasarana, dan sarana rumah susun termasuk fasilitas dan aksesibilitas bagi penyandang cacat dan lanjut usia, dan terakhir adalah asas keamanan, ketertiban, dan keteraturan sebagai landasan agar pengelolaan dan pemanfaatan rumah susun dapat menjamin bangunan, lingkungan, dan penghuni dari segala gangguan dan ancaman keamanan; ketertiban dalam melaksanakan kehidupan bertempat tinggal dan kehidupan sosialnya; serta keteraturan dalam pemenuhan ketentuan administratif.

Force majeure atau overmacht merupakan konsep hukum yang berasal dari hukum Roma (vis motor cui resisti non potest) yang diadopsi dalam berbagai macam sistem hukum. Doktrin dalam common law memaknai 
kata ini sebagai suatu ketidakmampuan untuk melakukan sesuatu prestasi terhadap suatu kontrak, dengan di analogikan tetapi tidak identik dengan overmacht. ${ }^{16}$

Force majeure atau keadaan memaksa adalah keadaan tidak dipenuhinya prestasi oleh debitur karena terjadi peristiwa yang tidak dapat diketahui atau tidak dapat diduga akan terjadi ketika membuat perikatan. Dalam keadaan memaksa, debitur tidak dapat disalahkan karena keadaan ini timbul diluar kemauan dan kemampuan debitor. Unsurunsur keadaan memaksa berdasarkan uraian diatas yaitu tidak dipenuhi prestasi karena terjadi peristiwa yang membinasakan atau memusnahkan benda objek perikatan, terjadi peristiwa yang menghalangi perbuatan debitor untuk berprestasi dan peristiwa itu tidak dapat diketahui atau diduga akan terjadi pada waktu membuat perikatan.

Akibat hukum ialah segala akibatyang terjadidari segalaperbuatan hukum yang dilakukan subjek hukum terhadap objek hukum yang disebabkan karena kejadian-kejadian oleh hukum yang bersangkutan yang telah ditentukan atau dianggap sebagai akibat hukum. Akibat hukum inilah yang kemudian menjadi sumber lahirnya hak dan kewajiban bagi subjek hukum yang bersangkutan.

16 Anonim, 2011, Force Majeure in Troubled Times: The Example of Libya, Jones Day Publication, Houston, hlm. 1
Rumusan force majeure menurut pasal-pasal tersebut yaitu :

Pasal 1444 KUHPerdata :

Jika barang tertentu yang menjadi pokok persetujuan musnah, tak dapat diperdagangkan, atau hilang hingga tak diketahui sama sekali apakah barang itu masih ada, atau tidak, maka hapuslah perikatannya, asal barang itu musnah atau hilang di luar kesalahan debitur dan sebelum ia lalai menyerahkannya.

Bahkan meskipun debitur lalai menyerahkan suatu barang, yang sebelumnya tidak ditanggung terhadap kejadian-kejadian yang tak terduga, perikatan tetap hapus jika barang itu akan musnah juga dengan cara yang sama di tangan kreditur, seandainya barang tersebut sudah diserahkan kepadanya. Debitur diwajibkan membuktikan kejadian tak terduga yang dikemukakannya.

Dengan cara bagaimanapun suatu barang hilang atau musnah, orang yang mengambil barang itu sekali-kali tidak bebas dan kewajiban untuk mengganti harga.

Pasal 1445 KUHPerdata :

"Jika barang yang terutang musnah, tak lagi dapat diperdagangkan, atau hilang di luar kesalahan debitur, maka debitur, jika ia mempunyai hak atau tuntutan ganti rugi mengenai barang tersebut, diwajibkan memberikan hak dan tuntutan tersebut kepada kreditur." 
Berdasarkan uraian pasal diatas maka force majeure dapat disimpulkan merupakan peristiwa yang tidak terduga yang terjadi di luar kesalahan debitur setelah penutupan perjanjian yang menghalangi debitur untuk memenuhi prestasinya, sebelum ia dinyatakan lalai dan karenanya tidak dapat dipersalahkan serta tidak menanggung risiko atas kejadian tersebut.

Menurut pendapat Mieke Komar Kantaatmadja yang dikutip oleh Harry Purwanto menyebutkan bahwa force majeure adalah:

1. Perubahan suatu keadaan tidak terdapat pada waktu pembentukan perjanjian.

2. Perubahan tersebut perihal suatu keadaan yang fundamental bagi perjanjian tersebut.

3. Perubahan tersebut tidak dapat diperkirakan sebelumnya oleh para pihak.

4. Akibat perubahan tersebut haruslah radikal, sehingga mengubah luas lingkup kewajiban yang harus dilakukan menurut perjanjian itu.

5. Penggunaan asas tersebut tidak dapat diterapkan pada perjanjian perbatasan dan juga terjadinya perubahan keadaan akibat pelanggaran yang dilakukan oleh pihak yang mengajukan tuntutan. ${ }^{17}$

Menurut pendapat Munir Fuady, istilahovermacht diterjemahkan

17 Harry Purwanto, Keberadaan Asas Rebus Sic Stantibus Dalam Perjanjian Internasional, Jurnal Mimbar Hukum Edisi Khusus, November 2011, hlm. 115 menjadi force majeure. Munir Fuady juga mengemukakan bahwa force majeure terhadap suatu kontrak dapat dibedakan sebagai berikut, yaitu:

1. Dilihat dari segi sasaran yang terkena force majeure, dibedakan menjadi 2 (dua) yaitu Force Majeure Objektif disebut juga dengan physical impossibility dan Force Majeure Subyektif;

2. Dilihat dari segi kemungkinan pelaksanaan prestasi dalam kontrak, force majeure dibedakan menjadi 2 (dua), yaitu Force Majeure Absolut atau sering disebut dengan impossibility dan Force Majeure Relatif atau sering disebut dengan impracticality

3. Dilihat dari segi jangka waktu berlakunya keadaan yang menyebabkan terjadinya force majeuredibedakan menjadi2(dua), yaitu Force Majeure Permanen dalam hal ini jika sama sekali sampai kapan pun suatu prestasi yang terbit dari kontrak tidak mungkin dilakukan lagi. Misalnya jika barang yang merupakan objek dari kontrak tersebut musnah diluar kesalahan debitur. Force Majeure Temporer dimana dalam pemenuhan prestasi dari kontrak tersebut tidak mungkin dilakukan untuk sementara waktu, misalnya karena terjadi peristiwa tertentu, dimana setelah peristiwa tersebut berhenti, prestasi tersebut dapat dipenuhi kembali. ${ }^{18}$

18 Munir Fuady, 1999, Hukum Kontrak (Dari Sudut Hukum Bisnis, Citra Aditya Bakti, Bandung, hlm. 114-117 
Menurut pendapat R. Setiawan akibat hukum dari terjadinya force majeure yang mengakibatkan menghentikan bekerjanya perikatan atau perjanjian yaitu :

a. Kreditur tidak lagi dapat meminta pemenuhan prestasi;

b. Debitur tidak lagi dapat dinyatakan lalai, dan karenanya tidak wajib membayar ganti rugi;

c. Risiko tidak beralih kepada debitur;

d. Kreditur tidak dapat menuntut pembatalan pada persetujuan timbal balik. ${ }^{19}$

Terjadinya suatu force majeure dalam pembangunan rumah susun tentunya berkaitan dengan risiko tanggung gugat bagi para pihak. Menurut pendapat Subekti, "risiko adalah kewajiban untuk memikul beban kerugian apabila terjadi peristiwa di luar kesalahan salah satu pihak yang menimpa benda yang dimaksud dalam perjanjian atau menghalangi pelaksanaan prestasi." ${ }^{20}$ Dalam kaitannya dengan rumah susun yang masih dalam proses pembangunan tentunya para pihak sama-sama mengalami kerugian baik dari pihak developer maupun pihak konsumen.

19 R. Setiawan, 1977, Pokok-Pokok Hukum Perikatan, Putra Abardin, Bandung, hlm. 2728

20 Subekti, 1976, Perbandingan Hukum Perdata, Pradnya Paramita, Jakarta, hlm. 144

\subsection{Penyelesaian Atas Keadaan Force Majeure Pada Rumah Susun Yang Masih Dalam Proses Pembangunan}

Perjanjian yang sering dilakukan oleh para pihak atau antara pihak pengembang dengan pihak konsumen perumahan yaitu dalam bentuk perjanjian baku, yaitu perjanjian yang klausula nya tidak bisa dan tidak dinegosiasikan atau ditawar pihak lainnya. Dalam perjanjian pengikatan jual beli rumah susun, pembeli belum memiliki hak sepenuhnya terhadap obyek jualbeliyangdalam haliniadalah rumah susun. Pembeli memiliki hak sepenuhnya atas rumah susun apabila sudah dilakukan penandatanganan akta jual beli, sehingga konsumen yang sudah melakukan pembayaran angsuran atas obyek jual beli bisa mendapatkan kepastian hukum. ${ }^{21}$

Kedudukanforce majeure berada di bagian hukum perjanjian yang merupakan bagian hukum perdata (private). Hukum ini menitikberatkan pada kewajiban dalam pelaksanaan kewajiban sendiri (self imposed obligation). Pelanggaran terhadap kewajiban-kewajiban yang ditentukan dalam kontrak, murni menjadi urusan pihak-pihak yang berkontrak menyebabkan hukum perjanjian ini menjadi bagian dari hukum perdata. ${ }^{22}$

21 Maria S.W Sumardjono, 2001, Kebijakan Pertanahan Antara Regulasi \& Implementasi, Buku Kompas, Jakarta, hlm. 161

22 M. Muhtarom, Asas-Asas Hukum Perjanjian: Suatu Landasan Dalam Pembuatan Kontrak, Jurnal Suhuf, Vol. 26, No. 1, Mei 2014, hlm. 50 
Sifat mutlak dan relatif force majeure menunjukkan pembedaan antara mutlak yang dikaitkan dengan pembatalan atau batal terhadap suatu kewajiban debitur, dengan relatif yang dairtikan dengan gugur. Pemusnahan objek perjanjian dikaitkan dengan pembatalan atau batal, sedangkan relatif menunjukkan suatu prestasi dapat dilakukan oleh debitur tetapi tidak memiliki nilai dalam pandangan kreditur. Persamaan dari sifat batal dan gugur force majeure adalah bahwa suatu perjanjian keduanya tidak mencapai tujuan dari perjanjian yang telah disepakati sebelumnya. ${ }^{23}$

Force majeure atau keadaan memaksa ini mengarahkan kepada teori penghapusan atau peniadaan kesalahan (afwesigheid van schuld), yaitu pemberian keringanan dalam hal debitur tidak dapat bertanggungjawab karena kesalahan tersebut bukan berasal dari debitur, terhadap suatu kewajiban yang seharusnya dilakukan. Teori ini memberikan arahan bahwa Pertama, debitur tidak perlu membayar ganti rugi (Pasal 1244 KUHPerdata). Kedua, beban resiko tidak berubah terutama pada keadaan memaksa sementara. Ketiga, kreditur tidak berhak atas pemenuhan prestasi, tetapi bersamaan dengan pembebasan dari kewajibannya untuk menyerahkan kontra prestasi, kecuali terhadap Pasal 1460 KUHPerdata. $^{24}$

23 Abdulkadir Muhammad, 1978, Hukum Perdata Indonesia, Alumni, Bandung, (selanjutnya disebut Abdulkadir Muhammad III) hlm. 206

24 Erlies Septiana Nurbani Salim, 2014, Perbandingan Hukum Perdata Comparative Civil Law, Rajawali Pers, Jakarta, hlm. 264
Apabila terjadi Force Majeure pada saat rumah susun tersebut masih dalam proses pembangunan bila dikaitkan dengan tuntutan ganti rugi atas uang muka yang sebelumnya telah dibayarkan oleh konsumen kepada developer maka berdasarkan ketentuan Pasal 1246 KUHPerdata, biaya, ganti rugi dan bunga yang boleh di tuntut oleh konsumen terdiri atas kerugian yang telah dideritanya dan keuntungan yang sedianya dapat diperolehnya tanpa mengurangi pengecualian dan perubahan yang di sebut di bawah ini. Akan tetapi mengingat adanya ketentuan Pasal 1244 KUHPerdata maka harus dapat dibuktikan terlebih dahulu bahwa tidak di laksanakannya perikatan tersebut disebabkan oleh hal yang tidak terduga dan tidak dapat dipertanggungjawabkan kepadanya.

Force majeure / overmacht pengaturannya di Indonesia terdapat dalam Pasal 1244 dan 1245 KUHPerdata, namun apabila dikaji lebih lanjut ketentuan tersebut lebih menekankan bagaimana tata cara penggantian biaya, rugi dan bunga akan tetapi dapat dijadikan acuan sebagai pengaturan force majeure. Pada klausa force majeure memberikan perlindungan yang diberikan dari terhadap kerugian yang disebabkan oleh kebakaran, banjir, gempa, hujan badai, angin topan, (atau bencana alam lainnya), pemadaman listrik, kerusakan katalisator, sabotase, perang, invasi, perang saudara, pemberontakan, revolusi, kudeta militer, terorisme, nasionalisasi, blokade, embargo, 
perselisihan perburuhan, mogok, dan sanksi terhadap suatu pemerintahan.

Pengaturan mengenai overmacht dalam rumah susun ini belum diatur dengan jelas dalam UU Rumah Susun, sehingga belum ada suatu kepastian hukum apabila terjadi keadaan overmacht tersebut. Konsumen apakah memiliki hak untuk menuntut kembali uang muka/ downpayment yang telah dibayarkan sebelumnyakepadapihakpengembang. Adapun upaya penyelesaian apabila terjadi keadaan force majeure apabila rumah susun yang masih dalam proses pembangunan yaitu:

1. Penyelesaian melalui musyawarah mufakat antara pihak pengembang selaku developer dengan pihak konsumen untuk menemukan penyelesaian bersama atas terjadinya keadaan force majeure.

2. Penyelesaian kerugian yang dilakukan melalui asuransi, sehingga klaim asuransi nantinya dipergunakan untuk melakukan pembangunan kembali rumah susun tersebut.

Force majeure untuk perjanjian jual-beli, khususnya mengenai resiko sebagai akibat dari force majeure diatur dalam Pasal 1460 KUHPerdata. Pasal 1460 KUHPerdata merupakan ketentuan terpenting sekaligus paling kontroversional dalam KUHPerdata yang menyatakan bahwa resiko atas barang tertentu yang diperjualbelikan akan ditanggung pembeli, karena itu bila barang musnah sebelum penyerahan karena force majeure, pembeli tetap harus membayar harga yang disepakati sekalipun pembeli tidak lagi akan dapat menerima barang yang dimaksud. ${ }^{25}$

\section{KESIMPULAN}

Dari pembahasan yang sudah dipaparkan diatas, oleh karena itu kesimpulan yang didapat adalah akibat hukum terjadinya keadaan force majeure pada saat rumah susun masih dalam proses pembangunan yaitu tidak lagi dapat meminta pemenuhan prestasi; Debitur tidak lagi dapat dinyatakan lalai, dan karenanya tidak wajib membayar ganti rugi; Risiko tidak beralih kepada debitur; Kreditur tidak dapat menuntut pembatalan pada persetujuan timbal balik. Adapun upaya penyelesaian apabila terjadi keadaan force majeure apabila rumah susun yang masih dalam proses pembangunan yaitu penyelesaian melalui musyawarah mufakat antara pihak pengembang selaku developer dengan pihak konsumen untuk menemukan penyelesaian bersama atas terjadinya keadaan force majeure. Penyelesaian kerugian yang dilakukan melalui asuransi, sehingga klaim asuransi nantinya dipergunakan untuk melakukan pembangunan kembali rumah susun tersebut. Disarankan kepada pihak pengembang hendaknya selalu menyertakan asuransi atas pekerjaan yang dilakukan sehingga

25 Suharnoko, Hukum Kontrak Dalam Perspektif Komparatif, Jurnal Indonesia Law Review, Vol. 2, edisi Mei-Agustus 2012, hlm. 104 
apabila terjadi keadaan force majeure risikonya dapat ditanggung oleh pihak asuransi. Dan kepada pihak konsumen hendaknya sebelum melakukan pembelian rumah susun yang masih dalam proses pembangunan, agar selalu meminta informasi yang detail kepada pengembang mengenai kemungkinankemungkinan yang akan terjadi pada saat pembangunan rumah susun masih berlangsung

\section{DAFTAR PUSTAKA}

\section{BUKU}

Anonim. (2011). Force Majeure in Troubled Times: The Example of Libya. Jones Day Publication. Houston.

Bambang, W. (2002). Penelitian Hukum Dalam Praktek. PT Sinar Grafika, Jakarta.

Fajar, M., \& Achmad, Y. (2010). Dualisme Penelitian Hukum Normatif dan Empiris. Pustaka Pelajar, Yogyakarta.

Fuady, M. (1999). Hukum Kontrak (dari sudut pandang hukum bisnis). Citra Aditya Bakti.

Halim, A. R. (2002). Sendi-Sendi HukumHakMilikKondominium, Rumah Susun Dan Sari-Sari Hukum Benda. Puncak Karna. Jakarta

Handri, R. (2009). Hukum Perjanjian di Indonesia. Pustaka Yustisia. Yogjakarta

Hutagalung, A. (2007). Kondominium dan Permasalahannya (edisi revisi). Badan Penerbit FHUI, Jakarta.

Kallo, E. (2009). Panduan Hukum Untuk Pemilik/Penghuni Rumah Susun. Minerva Athena Pressindo, Jakarta.

Muhammad, A. (1978). Hukum Acara Perdata Indonesia. Alumni. Bandung

Persada, J. (2003). Penelitian Hukum Normatif (Suatu Tinjauan Singkat). Rajawali Pers, Jakarta.

R. Serfianto Dibyo Purnomo, Iswi Hariyani dan Cita Yustisia. (2011). Kitab Hukum Bisnis Properti. Pustaka Yustisia. Yogjakarta

Salim, E. S. N., \& Nurbani, E. S. (2014). Perbandingan Hukum Perdata Comparative Civil Law. Rajawali Pers. Jakarta

Setiawan, R. (1977). Pokok-Pokok Hukum Perikatan. Binacipta. Bandung.

Soekanto, S. (2006). Pengantar penelitian hukum. Penerbit Universitas Indonesia (UIPress). Jakarta.

Subekti (R.). (1976). Perbandingan hukum perdata. Pradnya Paramita. Jakarta.

Sumardjono, M. S. (2006). Kebijakan pertanahan: antara regulasi dan implementasi. Penerbit Buku Kompas. Jakarta.

Sutedi, A. (2010). Hukum rumah susun \& apartemen. Sinar Grafika. Jakarta. 
Zainal, A. A. (2004). Pengantar Metode Penelitian Hukum. PT RajaGrafindo Persada, Jakarta

\section{ARTIKEL JURNAL}

Erfira, I., \& Walesa Putra, I. (2015).

TINJAUAN YURIDIS TERHADAP KEPEMILIKAN HAK ATAS TANAH PADA SATUAN RUMAH SUSUN. Kertha Negara, . Retrieved from https://ojs.unud.ac.id/ index.php/Kerthanegara/article/ view/13084

Hastuty, R. Y. (2015). Perlindungan Hukum terhadap Konsumen dalam Jual Beli Rumah Susun Komersial yang Belum Dibangun. Kumpulan Jurnal Mahasiswa Fakultas Hukum.

Muhtarom, M. (2014). Asas-Asas

Hukum Perjanjian: Suatu landasan Dalam Pembuatan Kontrak. Jurnal Suhuf, 26(1).

Purwanto, H. (2011). Keberadaan Asas Rebus Sic Stantibus dalam Perjanjian Internasional. Mimbar Hukum, 102-121.

Suharnoko. (2012). Hukum Kontrak Dalam Perspektif Komparatif, Jurnal Indonesia Law Review, 2(1)

Sujateruna, R., Puspawati, I., \& Putrawan, S. (2014). PERLINDUNGAN HUKUM BAGI KONSUMEN PEMBELI SATUAN RUMAH SUSUN TERHADAP STATUS KEPEMILIKAN SATUAN
RUMAH SUSUN. Kertha Semaya, . Retrieved from https://ojs.unud.ac.id/index. $\mathrm{php/Kerthanegara/article/}$ view/10270.

\section{PERATURAN \\ PERUNDANG-UNDANGAN}

Kitab Undang-Undang Hukum Perdata

UUD Negara Kesatuan Republik Indonesia Tahun 1945

Undang-Undang No. 20 Tahun 2011 tentang Rumah Susun

Undang-Undang No. 1 Tahun 2011 tentang Perumahan dan Kawasan Permukiman 